logos_i_ethos_2013_1_(34), s. 193-205

Mirosław Twardowski

\title{
Niezwykłe owoce twórczej współpracy genetyka z fizykami
}

Creating a Physical Biology. The Three-Man Paper and Early

Molecular Biology, eds. Phillip R. Sloan, Brandon Fogel, The University of Chicago Press, Chicago and London 2011, ss. 319

U przyczyn powstania książki Creating a Physical Biology. The Three-Man Paper and Early Molecular Biology, jak dowiadujemy się ze „Wstępu”, leży projekt badaw-

ks. Mirosław Twardowski - doktor, adiunkt w Zakładzie Polityki Regionalnej i Gospodarki Żywnościowej Uniwersytetu Rzeszowskiego. czy autorstwa Brandona Fogela i Phillipa Sloana poświęcony koncepcji życia we współczesnej biologii molekularnej. Częścią tego projektu było stworzenie tłumaczenia oraz opatrzenie komentarzem publikacji Nikołaja Władimirowicza Timofiejewa-Riesowskiego, Karla Zimmera oraz Maxa Delbrücka pt. O naturze mutacji genowej i strukturze genu [Über die Natur der Genmutation und der Genstruktur] z 1935 roku. Ze względu na niewielki nakład tej publikacji w wersji oryginalnej oraz brak angielskiego tłumaczenia wielu badaczy znało ją tylko $\mathrm{z}$ fragmentów cytowanych przez innych autorów. Okoliczności te, a także rola tej książeczki w powstaniu ważnego eseju Erwina Schrödingera Czym jest $\dot{z} y c i e$ ? [What Is Life?] (1944) sprawiają, że pełne tłumaczenie tego dzieła wraz ze stosownymi komentarzami okazały się niezmiernie potrzebne. Sympozjum na dorocznym spotkaniu Historii Towarzystwa Naukowego w 2005 roku umożliwiło autorom przygotowującym komentarze do wypracowania ich własnych poglądów na historyczny kontekst oraz znaczenie tej publikacji, a także wypracowanie wspólnej strategii dla tego dzieła jako całości. Niezwykle ważne okazało się zrozumienie znaczenie tej publikacji w ówczesnym kontekście historycznym, bez kierowania się 
interpretacją dostarczoną przez Schrödingera. Należało również zrozumieć ją poza kontekstem odkrycia struktury DNA. Wymagało to umiejscowienie dzieła w złożonym świecie Instytucji Naukowej Cesarza Wilhelma, w niespokojnym okresie ostatnich dni Republiki Weimarskiej. Wynikiem była zmiana spojrzenia na tę publikację. Geneza oraz przeznaczenie tego dzieła dla autorów Creating a Physical Biology okazały się nie być dokładnie tym, za co były uważane w literaturze. „O naturze mutacji genowej i strukturze genu” czytane w swoim historycznym kontekście okazuje się mieć intelektualne pochodzenie równie blisko związane $\mathrm{z}$ badaniami molekularnymi nad fotosyntezą, jak i z genetyką.

Recenzowana książka składa się ze wstępu, części historycznej, części filozoficznej, tekstu tłumaczenia poprzedzonego wstępem autora przekładu. W końcowej części książki znajdujemy bibliografię, listę współautorów publikacji oraz indeks zawierający nazwiska i terminy pojawiające się w tekście. Kolejne rozdziały są poświęcone naukowym, historycznym i filozoficznym kwestiom związanym z dziełem Timofiejewa-Riesowskiego, Zimmera i Delbrücka. Streśćmy krótko poszczególne części recenzowanej książki.

Rozdział pierwszy („Wprowadzenie”, s. 1-35), autorstwa Phillipa R. Sloana i Brandona Fogela, ma charakter wprowadzający w problematykę zawartą w Creating a Physical Biology. Artykuł O naturze mutacji genowej i strukturze genu został napisany w 1935 roku wspólnie przez trzech uczonych: rosyjskiego genetyka Nikołaja Timofiejewa-Riesowskiego ${ }^{1}$

$1 \quad$ Nikołaj Władimirowicz Timofiejew-Riesowski (1900-1981) studiował biologię w Uniwersytecie Moskiewskim pod kierunkiem genetyka populacyjnego Siergieja Czetwierikowa (18801959), jednak rosyjska wojna domowa uniemożliwiła mu ukończenie studiów. Po rewolucji, mimo iż nie uzyskał stopnia naukowego, utrzymał pozycję w instytucie badawczym Nikołaja Koltsowa (18721940). W 1925 roku został zaproszony do dołączenia do Instytutu Kaisera Wilhelma (IKW) do działu Badań Mózgu, zlokalizowanym w Buch, północno-wschodnich przedmieściach Berlina, w wyniku zawarcia znajomości z jego dyrektorem, Oskarem Vogtem (1870-1959). Pomimo nakazu powrotu do Związku Sowieckiego w 1937 roku, Timofiejew-Riesowski podjął decyzję, by pozostać w nazistowskich Niemczech, głównie z powodu powstania łysenkizmu w czasie rządów Stalina. Kontynuował swoją pracę w IKW pomimo wybuchu wojny między Niemcami a Związkiem Radzieckim w czerwcu 1941 roku. Po wojnie został aresztowany przez władze sowieckie, oskarżony o kolaborację z wrogiem i skazany na dziesięć lat ciężkich robót w obozie pracy w GUŁagu. W 1947 roku, kiedy Sowieci 


\section{oraz dwóch Niemców: fizyka radiacyjnego Karla Günthera Zimmera i fi- zyka teoretycznego Maxa Delbrücka³ . Praca ta była powszechnie znana}

zdali sobie sprawę, że może być użyteczny przy ich projekcie bomby atomowej, Timofiejew-Riesowski został przeniesiony do zakładu produkcyjnego uranu w pobliżu Swierdłowska na Uralu, gdzie został kierownikiem biofizycznej jednostki badawczej pracującej nad radiacją i biologią. Po rezygnacji Nikity Chruszczowa z urzędu premiera w 1964 roku, nowy premier, Leonid Breżniew, zezwolił na pewną liberalizację w nauce biologicznej i wyzwolenie spod państwowej kontroli. Timofiejew-Riesowski przeniósł się wtedy do nowego Instytutu Radiologii Medycznej w Obnińsku, na południe od Moskwy, gdzie zorganizował wydział genetyki i radiobiologii. Jednak jego reputacja wciąż jeszcze nie była zrehabilitowana, przez co został poddany dalszym prześladowaniom i ostatecznie zmuszony do porzucenia działalności naukowej w 1971 roku. Timofiejew-Riesowski pośmiertnie został zrehabilitowany przez Michaiła Gorbaczowa, stając się jednym z najbardziej celebrowanych naukowców, prześladowanych w czasie ery sowieckiej. Zob. Creating a Physical Biology. The Three-Man Paper and Early Molecular Biology, eds. P. R. Sloan, B. Fogel, Chicago and London 2011, s. 6-12.

2 Karl Günther Zimmer (1911-1988), autor drugiej części O naturze mutacji genowej i strukturze genu, otrzymał w czerwcu 1934 roku doktorat $\mathrm{z}$ fotobiofizyki na Uniwersytecie w Berlinie pod kierunkiem chemika fizycznego Maxa Bodensteina (1871-1942). Jeszcze przed ukończeniem swojego doktoratu, pod koniec 1933 roku, został przyjęty jako technik fizyki na oddziale radiologicznym w Cecilienhaus Hospital, zlokalizowanym w pobliżu głównego kampusu Instytutu Kaisera Wilhelma na południowo-zachodnich przedmieściach Berlin-Dahlem. Wspólnie z Timofiejewem-Riesowskim opracował intensywny program badań radiacji. Był także zatrudniony przez Stowarzyszenie Auer w Berlinie, które specjalizowało się w produkcji radionukleotydów, najpierw do celów naukowych, następnie zostały włączone do programu niemieckiej bomby atomowej. Po upadku Berlina w kwietniu 1945 roku został schwytany przez Sowietów jako naukowiec biorący udział w badaniach nad bombą atomową i przetransportowany do obozu wojennego w Krasnogorsku, a następnie przeniesiony do Sungul. Po wypuszczeniu w 1955 roku przyjął tymczasową posadę w Szwedzkim Instytucie Badań nad Lasem w Uniwersytecie Królewskim w Sztokholmie (1955-1956), a w 1957 roku został wyznaczony do kierowania Instytutem Biologii Radiacyjnej w Centrum Badań Nuklearnych w Karlsruhe, gdzie prowadził badania nad bakteriofagiem oraz strukturą DNA. Swoje ostatnie lata spędził jako emerytowany profesor na Uniwersytecie Ruprechta-Karola w Heidelbergu. Zob. Creating a Physical Biology..., dz. cyt., s. 12-13.

3 Max Delbrück (1906-1981), trzeci i najbardziej znany z całej trójki autorów O naturze mutacji genowej i strukturze genu, studiował astronomię i astrofizykę na Uniwersytecie w Tybindze, a następnie na Uniwersytecie Berlińskim i Uniwersytecie w Bonn. Na Uniwersytecie w Getyndze zdobył swój pierwszy stopień naukowy. Tam też został wciągnięty w pracę nad nową mechaniką kwantową, przygotowując pracę doktorską pod kierunkiem W. Heitlera (1904-1981) na temat mechaniki kwantowej chemicznych wiązań homopolarnych litu. Od września 1929 roku do marca 1931 roku studiował fizykę w Uniwersytecie Bristolskim, pracując w laboratorium fizycznym H. H. Willsa. Następnie w marcu 1931 roku przeniósł się do Kopenhagi, gdzie mógł studiować przez sześć miesięcy fizykę w słynnym Instytucie Fizyki Teoretycznej Nielsa Bohra. Od września 1931 roku do marca 1932 roku przebywał z Wolfgangiem Paulim w Zurychu, kontynuując badania z obszaru fizyki teoretycznej. Następnie powrócił do Bristolu, gdzie pracował z Lennardem-Jonesem do września 1932 roku, kiedy to opuścił Bristol na stałe i powrócił do Berlina. Już w Bristolu miał silne, choć 
jako „Praca Trzech” (Dreimännerwerk, Dreimännerarbeit), od czego pochodzi skrót 3MP, używany przez autorów Creating a Physical Biology $y^{4}$. Mimo iż konkretne naukowe konkluzje zawarte w 3MP nie przetrwały próby czasu, to jednak praca ta była kamieniem milowym w rozwoju nowej biologii molekularnej, zarówno metodologicznie, jak i koncepcyjnie. Niespotykana jak dotąd współpraca specjalistów z trzech różnych dziedzin: genetyki, fizyki teoretycznej i fizyki radiacyjnej okazała się bardzo owocna. Połączenie sił kilku naukowców z różnych dziedzin, które doprowadziło do powstania „Pracy Trzech”, w latach trzydziestych ubiegłego wieku, było czymś niezwykłym. I to wyróżnia tę pracę spośród innych opracowań z tego okresu. Kolejną rzeczą wyróżniającą „Pracę Trzech" jest jej celowo syntetyczny i teoretyczny charakter. Publikacja ta w dużej mierze wykorzystuje fakty dotyczące eksperymentalnych badań nad promieniowaniem i mutacją, i z tego względu jest cennym źródłem informacji. Jednakże wychodzi poza ten cel i rozwija konkretną teorię genu i mutacji genowej. W ten sposób pokazuje zarówno powiązania, a także ważne różnice pomiędzy własnymi rozstrzygnięciami

niesprecyzowane jeszcze, zainteresowanie biologią, w szczególności botaniką. W Berlinie pracował jako asystent badawczy fizyka nuklearnego, Lise Meitner (1878-1968), którą poznał w 1932 roku na seminarium Bohra. Pracował w sąsiedztwie Wydziału Instytutu Cesarza Wilhelma. Tego lata powrócił raz jeszcze do Kopenhagi na słynny wykład Bohra „Światło i życie”, który, jak się okazało, odmienił jego życie. Po powrocie do Berlina w pierwszej kolejności nawiązał kontakt z Timofiejewem-Riesowskim w Jednostce Genetyki w IKW dla Badań nad Mózgiem w Berlin-Buch, oraz z dwoma innymi badaczami z IKW w Jednostce Chemii w Dahlem - chemikiem fizycznym Kurtem Wohlem (1896-1962) oraz biochemikiem Hansem Gaffronem (1902-1979). Delbrück związał się profesjonalnie z genetyką i biologią dopiero po publikacji O naturze mutacji genowej i strukturze genu. Po tej publikacji w kwietniu 1935 roku wziął udział w konferencji zorganizowanej przez Bohra w Kopenhadze w dniach 27-29 września 1936 roku, poświęconej w głównej mierze kwestiom radiacji i genetyki. Pomimo rosnącego zainteresowania dziedziną biologiczną, Delbrück pozostał w IKW przy jednostce Lise Meitner aż do 1937 roku. Stowarzyszenie Rockefellera umożliwiło mu następnie podróż do Kalifornijskiego Instytutu Technologii, by wziął udział w badaniach nad genetyką i teorią doboru naturalnego u Drosophila. Tam spotkał się z badaniami Emory Ellis nad bakteriofagami. Dzięki temu sam zajął się bakteriofagami, widząc w nich o wiele bardziej odpowiedni przedmiot dla biofizycznych analiz niż muszka owocowa. To jego praca jako genetyka fagu doprowadzi go ostatecznie do zdobycia Nagrody Nobla. Zob. Creating a Physical Biology..., dz. cyt., s. 13-16.

$4 \quad$ My także zamiast używać w dalszej części niniejszej recenzji pełnej nazwy $O$ naturze mutacji genowej i strukturze genu, będziemy używali skrótu 3MP. 
a refleksjami innego pioniera w genetyce teoretycznej tego okresu, a mianowicie Hermanna Mullera. To właśnie te teoretyczne ambicje doprowadziły do włączenia teorii kwantowej do genetyki eksperymentalnej. „Praca Trzech” przedstawia również zestaw pytań badawczych i wyciąga wnioski na temat natury genu. Użycie technologii promieni $\mathrm{X}$ oraz „teorii celu” umożliwiło spojrzenie na gen jako na konkretną molekularną strukturę, a przez to dostarczyło wyjaśnienia wielu zjawisk biologicznych. Umożliwiło to nakierowanie kolejnych projektów badawczych na dokładne kwestie związane ze strukturą genową. Mimo iż historyczne znaczenie 3MP nigdy nie było podawane w wątpliwość, to jednak dostęp do niego był silnie ograniczony. 3MP opublikowane zostało w 1935 roku przez Akademię Nauk w Getyndze, w czasopiśmie, które przerwało działalność po zaledwie trzech wydaniach. W późniejszym czasie Delbrück stwierdził, że opublikowanie 3MP w „Nachrichten” było wydaniem „pogrzebu pierwszej klasy”. Wydanie pierwszego angielskiego tłumaczenia z załączoną analizą jego znaczenia historycznego oraz filozoficznego ma na celu, w zamierzeniu Autorów, zapewnić dostęp do tego wpływowego dzieła oraz ukazać jego oryginalny kontekst.

Artykuł wywarł duży wpływ na wielu badaczy, przez co był przedrukowywany i rozpowszechniany w ramach wybranej grupy ludzi. Przedruki te oprawione były w zieloną okładkę, przez co stały się znane jako „Zielony Pamflet [Green Pamphlet]”. W 1942 roku kopia Zielonego Pamfletu została użyczona przez Paula Ewalda, fizyka interesującego się krystalografią, innemu fizykowi, Erwinowi Schrödingerowi, który tak jak i on był uchodźcą z nazistowskiej Europy. Schrödinger w dużym stopniu bazował na tym artykule w swoich publicznych wykładach udzielonych na Trinity College w Dublinie w lutym 1943 roku, opublikowanych w 1944 roku w jego popularnym traktacie Czym jest życie? [What Is Life?], poświęconym naturze życia i dziedziczności. To poprzez tę publikację duża część anglojęzycznego świata poznała 3MP i jego zawartość. Intencją Schrödingera było użycie mechaniki kwantowej w celu wyjaśnienia natury organizmów biologicznych, a zwłaszcza stabilności ich informacji genetycznej w długim okresie czasu. Dwa z siedmiu rozdziałów książki austriackiego fizyka poświęcone są 
wyłącznie omawianiu wyników eksperymentów 3MP oraz modelu genu Delbrücka. Autorzy Creating a Physical Biology widzą jednak niezgodność między Schrödingerem a autorami 3MP w jednym istotnym aspekcie. Jednym z głównych wątków książki austriackiego fizyka jest twierdzenie, że kompletna redukcja organizmów biologicznych do fizycznych stała się możliwa poprzez mechanikę kwantową.

Wizja Schrödingera jest na wskroś redukcjonistyczna: geny określają organizm poprzez prawa fizyki. Pogląd ten nie znalazł się w 3MP, ani też nie zyskał poparcia jego autorów, co najwyraźniej jest widoczne w czwartej część artykułu, współtworzonej przez wszystkich trzech badaczy. Dla nich geny są tylko komponentami skomplikowanych systemów z wieloma częściami operacyjnymi, niebędącymi same w sobie wyjaśnieniem całych organizmów.

Część historyczną [„Historyczne pochodzenie «Pracy Trzech»”] rozpoczyna rozdział zatytułowany „Fizycy i geny: od Einsteina do Delbrücka” (s. 61-98), napisany przez Williama C. Summersa, skupia się na rozwoju „nowej fizyki”, której narzędzia, będące owocem ówczesnych prac naukowych na temat radioaktywności oraz fizycznej natury promieni X, zostały wykorzystane przez autorów 3MP. Autor tego rozdziału postrzega artykuł Timofiejewa-Riesowskiego, Zimmera i Delbrücka jako kamień milowy na drodze do powstania biologii molekularnej. Co było istotne w tym opracowaniu naukowym, i dlaczego stało się „kamieniem milowym"? Odpowiadając na to pytanie, Autor wskazuje na dwa znaczące aspekty w tym opracowaniu, które poruszyły wyobraźnię naukowców. Po pierwsze, była to odważna próba podjęcia zagadnień biologicznych przy użyciu nowych narzędzi, czyli fizyki kwantowej. Po drugie, opracowanie przedstawia świadomą współpracę pomiędzy genetykiem, biofizykiem oraz fizykiem atomowym, jako okazję przeniesienia perspektyw z różnych dziedzin w celu rozwiązania wspólnego problemu. Fizyk i biofizyk, obydwaj zainteresowani i będący na bieżąco z fizyką promieni X oraz fizyką cząsteczkową, podjęli współpracę z genetykiem, który był w szczególności zainteresowany mutacją. Współpraca pomiędzy przedstawicielami tak różnych dziedzin w tamtych czasach nie była zbyt powszechna, a nawet wydawała się dość dziwna dla 
wielu naukowców. Jednak współpraca ta nadała tej pracy duży autorytet i otworzyła drogę do powstania „nowej biologii”.

Rozdział trzeci („Biofizyka w Berlinie: Klub Delbrücka”, s. 61-98), napisany przez Phillipa Sloana opisuje szczegółowo sieć społeczną, z której narodziła się „Praca Trzech”. Tę sieć stanowi seria nieformalnych seminariów zorganizowanych przez Maxa Delbrücka jesienią 1934 roku. Ten mały „klub” początkowo składał się z fizyków teoretyków, jednakże z czasem dołączyli do niego również genetycy, biochemicy i fizjologowie. W swoim wspomnieniu Delbrück wylicza członków tej grupy: Hansa Gaffrona, Gerta Molièrea, Wernera Blocha, Ernsta Lamię, Karla Waltera Kofinkę, Karla G. Zimmera oraz Nikołaja Timofiejewa-Riesowskiego. Dyskusje te, zorganizowane przez Delbrücka, były pierwszą próbą przeniesienia „ducha kopenhaskiego” w kontekst bezpośrednich powiązań biologii i fizyki zogniskowanych na fenomenie życia. Delbrück nasiąkł tym duchem, kiedy był młodym fizykiem uczęszczającym na seminaria z fizyki teoretycznej prowadzone co roku przez Nielsa Bohra.

Ostatni rozdział historyczny, zatytułowany „Wskrzeszając «Pracę Trzech»: Teoretyczne badania teorii celu w latach trzydziestych i czterdziestych”, s. 99-142), autorstwa Richarda H. Beylera, zajmuje się losem „teorii celu” po 1935 roku. W rozdziale tym Beyler podkreśla ważność tej teorii, a także omawia teoretyczne problemy, jakie napotkała. Ponadto znajdziemy w nim informacje dotyczące odbioru „Pracy Trzech” i sposobu, w jaki jej twierdzenia zostały zmodyfikowane w odpowiedzi na krytykę.

Na część filozoficzną recenzowanej książki [„Filozoficzne perspektywy «Pracy Trzech»”] składają się dwa rozdziały: „Niels Bohr i Max Delbrück: Balansowanie między autonomią i redukcjonizmem w biologii”, s. 145-178 oraz „Czy Delbrück był redukcjonistą?”, s. 179-210. Obydwa rozdziały skupiają się na kwestii redukcjonizmu w biologii w odniesieniu do poglądów Bohra i Delbrücka.

W pierwszym z wymienionych rozdziałów o charakterze stricte filozoficznym Nils Roll-Hansen próbuje wypracować dokładniejsze zrozumienie relacji pomiędzy filozofią nauki Bohra a biologicznym programem badawczym Delbrücka. Max Delbrück, jako młody fizyk, zainspirowany 
przez innego fizyka, Nielsa Bohra, zainteresował się problemami biologicznymi, by w końcu oprzeć na nich swoją naukową karierę. Spekulacje duńskiego fizyka na temat związku biologii i fizyki, wyłożone w wykładzie "Światło i życie”, wygłoszonym podczas Międzynarodowego Kongresu Terapii Światłem w Kopenhadze w październiku 1932 roku wpłynęły na wyobraźnię i rozwój kariery Delbrücka i ostatecznie doprowadziły go do Nagrody Nobla za badania nad genetyką fagu. Niemiecki fizyk nieustannie odnosił się do lektury „Światło i życie” jako do swojej wielkiej inspiracji dla kariery w biologii molekularnej.

Delbrück postrzegał biologię jako potencjalne źródło zjawisk, których wyjaśnienie wymagało nowych przełomowych postępów w fizyce, czy wręcz nowej rewolucji w fizyce, zbliżonej do przejścia od klasycznej mechaniki do kwantowej oraz teorii względności, która miała miejsce parę dekad wcześniej. Pomysł ten nie był obcy Bohrowi, ale były między obydwoma fizykami istotne różnice. Bohr był niewątpliwie zwolennikiem filozoficznego antyredukcjonizmu. Dostrzegał znaczące różnice pomiędzy biologią a fizyką. Użył nawet analogii pomiędzy sytuacją $\mathrm{w}$ fizyce atomowej przed teorią kwantową a obecną sytuacją w fizjologii. Tak jak stabilność atomów nie mogła być wyjaśniona przez klasyczną fizykę, podobnie życie, zdawało się być zjawiskiem niedostępnym dla kompletnej analizy w znaczeniu fizykochemicznym, ponieważ badanie zabiłoby organizm na długo, nim struktura molekularna zostałaby opisana w detalach. Osobliwość życia zdawała się tkwić w złożoności molekuł nieosiągalnych dla dostępnych metod fizyki i chemii. Dlatego też żywił przekonanie, że żywe organizmy nigdy nie mogą być w pełni wyjaśnione za pomocą fizyki i chemii. Koncepcja Bohra dotycząca autonomii biologii miała głębsze filozoficzne fundamenty w postaci konstruktywnego realizmu Haralda Høffdinga, który nie akceptował fizyki jako podstawowej nauki przyrodniczej.

W przekonaniu Autora program biologiczny Delbrücka znacząco różnił się od Bohra, był na wskroś redukcjonistyczny, w tym sensie, że szukał fizycznych i chemicznych wyjaśnień zjawisk biologicznych. Niemiecki fizyk podszedł więc do biologii w duchu metodologicznego redukcjonizmu. Ostatecznie jego pogląd był bliższy fizycznemu redukcjonizmowi 
Schrödingera, który nie pojmował filozofowania Bohra odnośnie do komplementarności. Jednak jego konkretną motywacją do wkroczenia $\mathrm{w}$ dziedzinę doświadczalnej biologii molekularnej była nadzieja na odkrycie paradoksów prowadzących do nowej rewolucji w fizyce. Choć duński fizyk szybko odkrył, że program redukcjonistyczny Delbrücka nie odzwierciedlał jego własnych filozoficznych poglądów, jednak sam nigdy nie zaangażował się w empiryczne badania biologiczne.

W drugim rozdziale o zabarwieniu filozoficznym Daniel J. McKaughan również podejmuje temat relacji między fizyką i biologią. W przeciwieństwie do Nilsa Roll-Hansena, który twierdził, że Delbrück był motywowany redukcjonizmem z zasady, McKaughan wyraża przekonanie, że Bohr i Delbrück dzielili te same oczekiwania odnośnie do tego, że przynajmniej niektóre aspekty życia okażą się być nieredukowalne w fizykochemicznym sensie. Autor rozdziału ostro krytykuje sugestię, wyrażaną przez Fuersta i innych, że 3MP powinno być czytane jako próba inauguracji fizykochemicznego redukcjonizmu, który uformował „duchowy symbol" części historii fagu w biologii molekularnej. Program badawczy, którym kierował się Delbrück w swym podejściu do problemów biologicznych, Autor nazywa „empirycznym antyredukcjonizmem”. McKaughan wskazuje przy tym na istotną różnicę $\mathrm{w}$ sposobie, $\mathrm{w}$ jaki obaj przyrodnicy dotarli do myśli o biologicznej komplementarności. Delbrück, w przeciwieństwie do Bohra będącego pod urokiem teleologii, zdawał się nie postrzegać jej jako kwestii kluczowej.

McKaughan twierdzi, że każda adekwatna ocena myśli Delbrücka musi brać pod uwagę następujące fakty. Po pierwsze, Delbrück podobnie jak Bohr twierdził, iż życie być może nie podlega redukcji do fizyki i chemii, wymagając w zamian odniesienia do jakiejś formy komplementarności, która była trudna do określenia w precyzyjnych terminach. Po drugie, Delbrück sam wyruszył na zbadanie kwestii empirycznych w biologii z nadzieją na natrafienie eksperymentalnego ograniczenia dla projektu redukcjonistycznego. Język o nieredukowalności to jest sposób, w jaki Bohr i Delbrück opisują swoje własne poglądy. Oczywiście należy pamiętać, że kontekst, w którym Bohr i Delbrück użyli języka nieredukowalności w biologii, był bardzo różny. Refleksje Bohra w tych 
kwestiach były osadzone $\mathrm{w}$ nieprzerwanej debacie pomiędzy neomechanicystami a neowitalistami na przełomie XIX i XX wieku. Nie brakuje więc komentarzy Bohra, gdzie jasno mówi o sytuacji, gdzie relacjonuje, że stanowiska powyższe wzajemnie się wykluczają, jednak razem są potrzebne relacji komplementarności. Delbrück, w czasach gdy biologia molekularna osiągnęła dojrzałość, miał nadzieję dowiedzenia antyredukcjonistycznych spekulacji Bohra.

McKaughan, kończąc swoje rozważania, nawiązuje do pytania postawionego w tytule rozdziału. Zacytujmy ten fragment: „Jeśli jednak Delbrück ma przyzwolenie do mówienia swoim własnym głosem - a kogo innego powinien zapytać historyk? - odpowiedź na pytanie postawione w tytule tego rozdziału musi być negatywna. Rzeczywiście, Horace Judson zapytał Delbrücka bezpośrednio o próbę dostarczenia kompletnego obrazu zjawiska, wliczając w to nasze własne istnienie. Judson zapytał, «Cała nauka była wyłącznie redukcjonistyczna na tym poziomie?», Delbrück odparł, dystansując się od redukcjonizmu «Nie redukcjonistyczna, myślę, że nauka taka, jaką mamy obecnie, prowadzi zdeprawowany żywot. Widoczne jest to bardzo jasno, kiedy próbujesz uprawiać psychologię. Czy chcesz postrzegać niepokój jako zjawisko hormonalne, czy też spojrzeć na to jako na zjawisko egzystencjalne? A jeśli patrzysz na to jako na zjawisko egzystencjalne, to jak możesz to wtedy włączyć do swojego obrazu nauki?». «[...] przegapiłbyś wiele aspektów, które chciałbyś zrozumieć»"

Na ostatnią część książki [„Praca Trzech”] składają się: wstęp tłumacza (s. 213-220), tekst tłumaczenia (s. 213-271) oraz odnośniki (s. 272-280).

We wstępie tłumacz Brandon Fogel streszcza treść kolejnych części „Dzieła Trzech”.

Część pierwsza, „Badanie eksperymentalne”, autorstwa Timofiejewa-Riesowskiego, jest najobszerniejsza ze wszystkich czterech (obejmuje ok. 50 procent całości). Podsumowuje ona ówczesny stan badań eksperymentalnych na genach i mutacji. Timofiejew-Riesowski zauważa, że koncepcja genu ewaluowała $\mathrm{z}$ formalnej do konkretnej. Geny są teraz rozumiane nie tylko jako abstrakcyjne dyferencyjne właściwości, ale jako 
część przestrzennie stałego i uporządkowanego materialnego systemu. Niemniej jednak twierdzi, że nie możemy wnioskować zbyt wiele o naturze genów. Geny są tylko częścią większego rozwojowego systemu, którego komórki są bardziej naturalnymi, fundamentalnymi jednostkami. Ponadto, wymagana jest bardziej bezpośrednia manipulacja genów, by dowiedzieć się czegoś o ich strukturze, a napromieniowywanie promieniami X dostarcza odpowiedniego do tego celu narzędzia.

Timofiejew-Riesowski uważa, że eksperymentalnie uruchomione mutacje nie różnią się jakościowo od tych powstałych spontanicznie. Napromieniowywanie jest lepszym rozwiązaniem niż inne wyzwalacze ze względu na możliwość starannego dawkowania, a poza tym promienie $\mathrm{X}$ oraz gamma łatwo docierają do jądra komórki, sprawiając, że ich działanie na materiał genetyczny jest dużo bardziej bezpośrednie od innych wyzwalaczy, takich jak poddawanie działaniu chemii.

Timofiejew-Riesowski nawiązuje niemal wyłącznie do eksperymentów z napromieniowywaniem muszki owocowej, Drosophila melanogaster. Na podstawie zebranych danych doświadczalnych pragnie udowodnić, że efekty wyzwalające mutację są proporcjonalne do użytej dawki lub dostarczonej ogólnie energii, oraz w dużym stopniu niezależne od metody jej aplikacji. Proporcjonalność wskaźnika mutacji w zależności od dawki sugeruje, że radiacja nie wpływa bezpośrednio na geny, ale raczej pośrednio poprzez jonizację okolicznej materii.

Na koniec Timofiejew-Riesowski sprawdza wskaźnik mutacji dla poszczególnych mutacji u Drosophila. Ponieważ wskaźniki mutacji się różnią, konkluduje, że wskaźnik każdej określonej mutacji jest uzależniony od fizycznej struktury zaangażowanych alleli.

Część druga, „Teoria celu”, autorstwa Zimmera, jest najkrótszą ze wszystkich. Niemiecki biofizyk omawia teorię celu, zestawu eksperymentalnych metod i teoretycznych technik do dedukowania faktów o fizycznej naturze materiału genetycznego.

Zimmer wskazuje na trzy możliwe drogi zmierzające do osiągnięcia „trafienia w cel” na genie, gdzie użyte do tego były promienie X: (1) kwant radiacji może trafić bezpośrednio w gen, (2) gen może być trafiony przez drugi elektron, który został przeniesiony z sąsiedniego 
atomu poprzez kwant radiacji, lub (3) para jonów, stworzonych przez zadziałanie na drugi elektron, może doprowadzić do interakcji z genem. Każda $z$ tych możliwych alternatyw trafienia w cel prowadzi do różnych empirycznych prognoz w zależności od różnych cech poszczególnych radiacji. Rozpatruje on każdą z nich. Jedyną realną opcję widzi w trzeciej drodze.

Część trzecia, „Fizyczny model mutacji”, autorstwa Delbrücka, jest koncepcyjnie najbardziej interesująca spośród wszystkich czterech. Delbrück używa fizyki teoretycznej w eksperymentalnej materii omawianej we wcześniejszych częściach, dochodząc do wniosku, że gen jest dużą molekułą oraz że mutacja zawiera stabilny układ z molekułą, działający albo przez losową fluktuację termiczną, albo też zewnętrzny napływ energii.

Ostatnia część, „Teoria mutacji genów i ich struktury”, autorstwa wszystkich trzech badaczy, zawiera ogólny opis poszczególnych części. Autorzy ukazali konsekwencje modelu Delbrücka, potwierdzające teorię genu. W swych konkluzjach nie posuwają się jednak dalej niż sam Delbrück w części trzeciej. Omawiają również eksperymenty, które mogą mieć miejsce w przyszłości, a które mogłyby testować ich model i prowadzić do udoskonalenia go. W trzech ostatnich paragrafach Autorzy powtarzają swoje stanowisko, że są przeciwko traktowaniu genów jako głównych kontrolerów procesu rozwojowego. Praca zarówno zaczyna się, jak i kończy zachętą dla badaczy z dziedzin związanych z genetyką, aby używali tylko tych „koncepcji genów, które są budowane na istotnych i często decydujących danych dotyczących poszukiwanych mutacji”.

Praca autorów Creating a Physical Biology zasługuje na szczególne uznanie. Po prawie osiemdziesięciu latach od ukazania się „Pracy Trzech” Autorzy ci zdecydowali się rozpowszechnić wśród szerokiej rzeszy czytelników tę niezwykle cenną pozycję ze względu na zawarty w niej szczególny rodzaj połączenia teorii fizycznej i biologicznej, który zyskał uznanie w środowisku naukowców z lat trzydziestych minionego wieku. Nie ograniczyli się tylko do, w mojej ocenie, bardzo wiernego, przekładu „Pracy Trzech” na język angielski. Autorzy Creating a Physical Biology 
wyciągają wiele nowych, interesujących, dotąd nieznanych wniosków płynących ze współpracy Timofiejewa-Riesowskiego, Zimmera i Delbrücka. Wnioski te omawiają szczegółowo w niezwykle czytelny sposób w kolejnych rozdziałach swej książki. Szczególnego podkreślenia wymagają źródła, do których odwołują się Autorzy, niektóre trudnodostępne dla ogółu czytelników. Książka Creating a Physical Biology jako dzieło zespołowe imponuje wiedzą i głębokim wniknięciem w istotę problemu, związanego z pytaniem „,czym jest życie?”, który od dziesiątków lat przykuwał i wciąż elektryzuje uwagę przyrodników i filozofów. Gorąco polecam ją wszystkim czytelnikom. 